\title{
Calving intervals, long-range movements and site fidelity of southern right whales (Eubalaena australis) in south-eastern Australia
}

\author{
M. Watson ${ }^{1 *}$, K. Stamation ${ }^{2}$, C. Charlton $^{3}$ and J. Bannister \\ Contact e-mail: mandy.watson@delwp.vic.gov.au
}

\begin{abstract}
Southern right whales in south-eastern Australia are endangered and vulnerable to impacts from human disturbance. Information on population demographics and movement data is needed to inform ongoing species management. While the number of whales observed using the south-eastern Australian coastline is increasing, there has been no change over three decades in the annual abundance of cow-calf pairs at Logans Beach in Warrnambool, Victoria, the only established calving ground in south-east Australia. Knowledge of life history parameters of the south-eastern Australian subpopulation is lacking. Here, we examine sightings and photo-identification data from southern Australia to investigate calving intervals, long range movements and fidelity to the Logans Beach calving ground. Sightings data revealed at least 93 calves were born at Logans Beach between 1980 and 2018 (an average of 2.6 per year) with a mean calving interval of $3.5 \pm 0.2$ years $( \pm S E, n=34$ ). Comparison between photo-identification catalogues compiled for south-eastern and south-western Australia shows that southern right whales are wide ranging within southern Australian waters. Females can be sighted at locations as far apart as $3,800 \mathrm{~km}$ across seasons with at least $7 \%$ of whales using both regions. We also provide the first report of an Australian southern right whale female belonging to one subpopulation relocating long-term to a calving area in another. This work highlights knowledge gaps for the south-east Australian subpopulation such as the proportion of female calves born at Logans Beach returning to their natal site and the degree of mixing between the two Australian subpopulations outside their wintering areas. Our work provides the first assessment of calving rates, movement and site fidelity within the south-eastern Australian subpopulation, critical for understanding constraints to recovery and informing conservation management of southern right whales in Australia. Targeted, long-term monitoring programs across south-eastern Australia are needed to provide demographic information on which to base assessments of the impacts of anthropogenic threats such as noise disturbance, entanglement and vessel strike.
\end{abstract}

KEYWORDS: CONSERVATION; DISTRIBUTION; FEEDING GROUNDS; HISTORICAL WHALING; MIGRATION; MONITORING; MOVEMENTS; NOISE; NURSERY GROUND; SITE FIDELITY; TRENDS

\section{INTRODUCTION}

Southern right whales were targeted for commercial hunting between 1790 and 1980, with at least 150,000 killed globally (Jackson et al., 2008). Within New Zealand and eastern Australia alone, over 58,000 southern right

\footnotetext{
${ }^{1}$ Barwon South West Regional Services, Department of Environment, Land, Water and Planning, 703 Raglan Parade, Warrnambool, Victoria, Australia 3280.

${ }^{2}$ Arthur Rylah Institute for Environmental Research, Department of Environment, Land, Water and Planning, PO Box 137, Heidelberg, Victoria, Australia 3084.

${ }^{3}$ Centre for Marine Science and Technology, Curtin University Western Australia. Kent Street, Bentley, Perth Western Australia.
} 
whales were taken with approximately 19,000 harvested from south-eastern Australian waters (Carroll et al., 2014). Historically, much of the western Victorian, eastern Tasmanian and southern New South Wales (NSW) coastlines were considered high-use areas for southern right whales (Fig. 1; DSEWPaC, 2012). It is thought that local extirpation has led to a loss of cultural memory of calving areas within this region contributing to the limited recovery of the south-eastern Australian subpopulation (Carroll et al., 2015).

There are two southern right whale subpopulations in Australia showing contrasting patterns of recovery since whaling ceased. The south-western Australian subpopulation uses the coastal waters of Western Australia (WA) and South Australia (SA) and the south-eastern Australian subpopulation uses the coastal waters of Victoria, NSW and Tasmania (Carroll et al., 2011; Carroll et al., 2015; Fig. 1). The south-western southern right whale subpopulation has several established and emerging calving grounds, while the south-eastern subpopulation currently has only one established calving ground; Logans Beach at Warrnambool in south-west Victoria. The south-western Australian subpopulation was estimated at 3,164 individuals in 2019 and is increasing at a rate of $6 \%$ per annum (Smith et al., 2020). The estimate for the south-eastern subpopulation is approximately 268 individuals with an overall increase of $4.7 \%$ per annum (Stamation et al., 2020). These population estimates are well below pre-whaling numbers and although the current growth rates in the two subpopulations are not significantly different there has been no significant increase in the annual numbers of females using the southeast Australian calving ground (Stamation et al., 2020).

The current Australian population delineation is based on Carroll et al. (2011), who found significant genetic differentiation between calving grounds in south-western Australia and south-eastern Australia (Logans Beach). Later work by (Carroll et al., 2015), questioned the degree of differentiation between the two regions. The latter study included pooled samples from the Logans Beach calving ground along with samples from western Victoria, Tasmania, NSW and QLD and pooled samples from Cape Jervis and Encounter Bay in South Australia and Bremer Bay and Doubtful Island Bay in Western Australia. Comparisons between the two regions using the pooled samples showed no genetic differentiation despite clear differences between the calving grounds and previous photo identification matching efforts in Australia have detected long range movements between south-eastern Australia, south-western Australia and New Zealand (Burnell, 2001; Pirzl et al., 2009). It is currently accepted

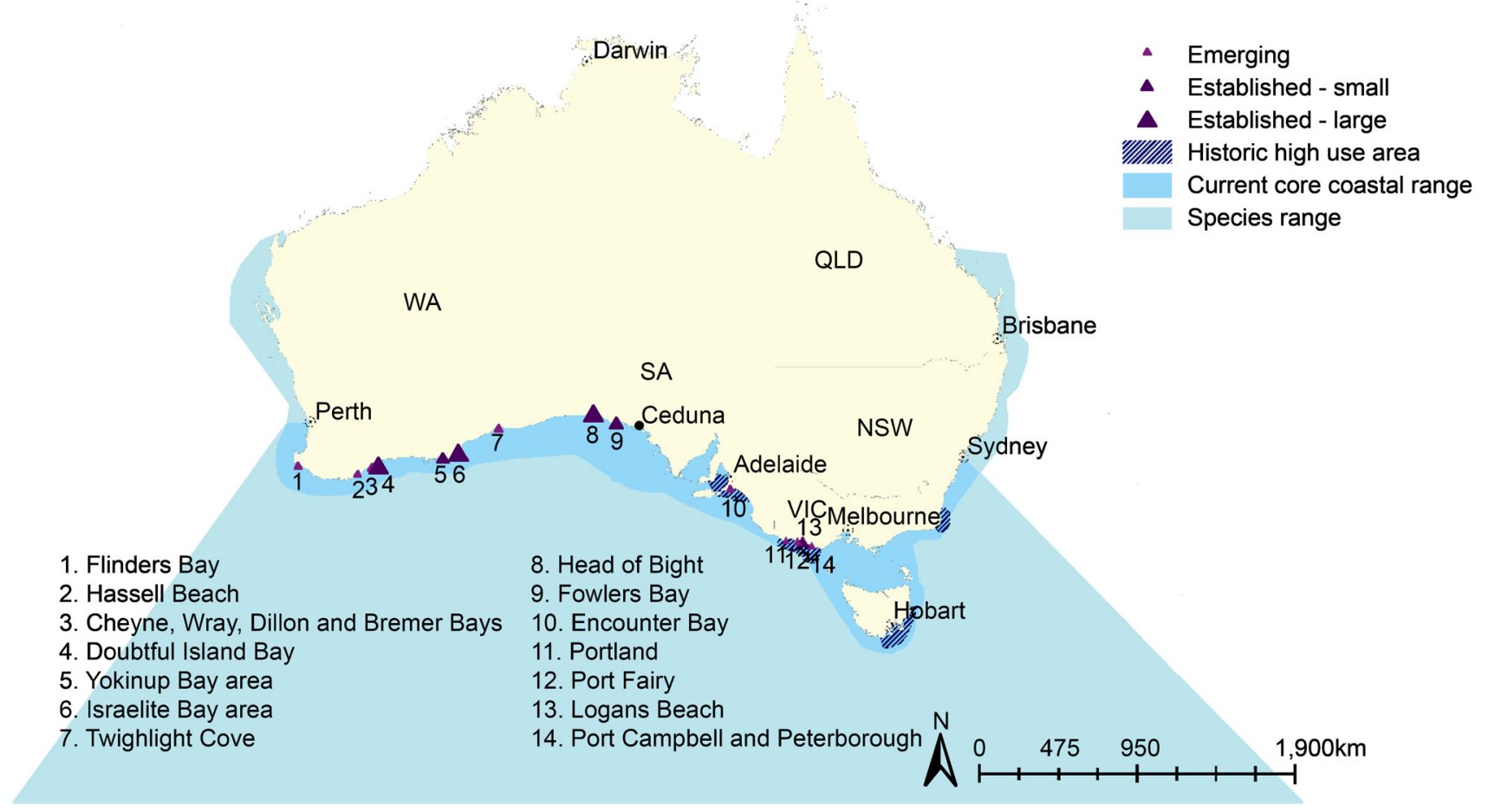

Fig. 1. Current distribution and historical high-use areas of the southern right whale in Australia. Adapted from DSEWPaC, 2012. NSW: New South Wales, QLD: Queensland, SA: South Australia, TAS: Tasmania, VIC: Victoria, WA: Western Australia. 
that the south-western and south-eastern calving grounds represent genetically distinct subpopulations but there appears to be some overlap in the wintering range of the two subpopulations.

Population demographics and life history parameters are fundamental to the assessment of population viability and rate of increase analyses (Brandão et al., 2011; Brandão et al., 2018; Cooke et al., 2001; Skalski et al., 2005; Zerbini et al., 2010). Population estimates and life-history parameters for the south-western subpopulation, such as calving interval, site fidelity, movement patterns and seasonality, have been quantified from cliff-based surveys and aerial surveys (Bannister, 2018; Burnell, 2001; Burnell, 2008; Charlton, 2017; Charlton et al., 2019a; Pirzl et al., 2009). However, comparative data on the south-eastern subpopulation are lacking. Long-term datasets that enable assessment of changes in life-history parameters over time are critical for conservation and management (Harcourt et al., 2019). This study, as well as Stamation et al. (2020) provides the first analysis of long-term photo-identification and observational data for the south-eastern Australian southern right whale subpopulation.

The South East Australia Southern Right Whale Catalogue (SEA SRW PIC) houses photo-identification data collected from 1993 across south-eastern Australia (i.e. Victoria, Tasmania and NSW) and the stretch of the SA coastline east of Ceduna to the Victorian border. This stretch was once considered part of the south-eastern subpopulation's region but Carroll et al. (2015) suggest all of South Australia's coast is included in the southwestern subpopulation's distribution. Here, we provide the results of a comparison of the SEA SRW PIC with the Australasian Right Whale Photo Identification Catalogue (ARWPIC) using data from 1993-2015 and include details of individual matches and movements between regions. We also provide the first report on calving intervals and site fidelity of identified females at Logans Beach, where sighting records have been collected since 1985 . This work will help inform conservation management of the heavily depleted south-eastern Australian subpopulation.

\section{METHODS}

\section{Sighting data}

Incidental southern right whale sighting records were collected and maintained by Victorian Government staff at Logans Beach $\left(38.404^{\circ} \mathrm{S}, 142.521^{\circ} \mathrm{E}\right)$ from 1985 , primarily for the purpose of monitoring seasonal whale numbers. With the creation of a south-eastern Australian southern right whale photo-identification network, sightings from across Victoria, Tasmania, NSW and SA were also collected from the early 2000s onwards. Here we used data collected until 2018. Data collectors (observers) primarily included State government agency staff and researchers but also whale-watching volunteers and tour operators, local government employees and members of the public. The minimum observation data collected were date, time, location, reproductive status (where calves were observed) and number of whales (with minimum and maximum values when numbers were uncertain). Since 2007, consistent observations were made by one volunteer whale watcher at the Logans Beach whale-watching platform for a minimum of $6 \mathrm{~h}$ per day, every day during the whale-watching season (April/May to September/October). This observer recorded all whale sightings (including behavioural observations) every $30 \mathrm{~min}$ each day. All data were housed in a relational database and underwent quality assurance checks to ensure consistency and accuracy in the dataset. Only data that were validated either by images and/or contributed by observers known to be able to identify whales to species level were included in the analyses.

\section{Photo-identification data}

Photo-identification is a non-invasive research method that can be used to investigate the distribution, movement and population trends of some species. Southern right whales have unique callosity patterns formed by patches of thickened, keratinised tissue around the head which allow for the photo-identification of individuals (Bannister, 1990; Best, 1990; Burnell, 2001; Payne et al., 1983; Pirzl et al., 2009). The SEA SRW PIC was established in 2001 and includes callosity images collected from 1993 onwards in south-eastern Australia, including SA (east of Ceduna), Victoria, Tasmania and NSW. These images were collected during dedicated photo-identification flights, aerial population surveys and boat-based biopsy sampling activities (Watson et al., 2015), during opportunistic whale monitoring and sightseeing flights, and from members of the public from land-based and vessel-based 
platforms. Only whales with images suitable for photo-identification were included in the catalogue. Features of each whale's callosity pattern were coded and other conspicuous markings (such as belly blazes) were noted. Whales were catalogued only when callosity patterns could be coded with certainty. Multiple images of the same whale including images from different angles were utilised if image quality was low, or callosities were obscured. These data, along with their associated metadata, were stored in a Microsoft Access database containing a codingbased matching system known as BigFish ${ }^{4}$. Each sighted whale was cross-checked against previously catalogued whales using the BigFish CodeCompare protocol (Pirzl et al., 2007). If a match was found the sighting was added to the catalogue. If a full search of the entire catalogue was made with no match found the sighted whale was catalogued as a new individual.

\section{Photo-identification matching}

The SEA SRW PIC was cross-referenced against the ARWPIC in 2016. At that time, SEA SRW PIC contained 343 whales sighted in south-east Australia between 1993 and 2015 and ARWPIC contained 1,576 whales sighted in south-western Australia in 1978-2011 (catalogued by J. Bannister). The ARWPIC also included 109 individuals sighted in Tasmania between in 2011-2014 which are also included in the SEA SRW PIC). These whales were excluded from the SEA SRW PIC/ARWPIC cross matching. Cross-matching of the remaining 234 whales in the SEA SRW PIC was performed as per the matching protocols described in the ARWPIC user guide ${ }^{5}$. The matching protocol involves a six-step search process, starting with the tightest search (i.e. coding the maximum number of features available (according to the protocols) and then broadening the search by removing features at each step. We did not perform all six searches available in the ARWPIC for each whale, although at least the first three searches were performed. This approach was considered appropriate given that the latter searches returned whales with callosities that had been coded differently or were not seen, therefore the chances of being able to make a positive identification with a high degree of confidence were low in the last available searches. Known breeding females from Logans Beach were also cross-matched against the Head of Bight (Eubalaena Pty. Ltd.) and Fowlers Bay, South Australian photo-identification catalogues. All matches and new individuals were validated by a minimum of two photo-identification experts.

\section{RESULTS}

Between 1993 and 2018, 375 individual whales (including 48 breeding females) were identified in south-eastern Australia (east of the SA/Victorian border). Twenty-one of these individuals (6\%) were resighted within the southeastern Australian region at least once in a different year. Seventy-six percent of these re-sights were breeding females and the remaining were of unknown sex. Of these resights, only two females were sighted in southeastern Australian waters the year prior to calving.

\section{Calving intervals at Logans Beach}

Fifty-one individuals were identified at the Logans Beach calving ground at Warrnambool between 1995 and 2018 and 15 of these were females accompanied by a calf (Table 1). In 2013 a female with a calf resided in the Portland area for 35 days, approximately $100 \mathrm{~km}$ west of Logans Beach, and in 2017 an additional female with a calf was identified in a nearby bay $\left(38.355^{\circ} \mathrm{S}, 142.337^{\circ} \mathrm{E}\right)$ approximately $17 \mathrm{~km}$ west of Logans Beach. This pair spent a minimum of 44 days in the bay. Two females (SE0102 and SE0201) recorded in previous years at Logans Beach spent most of the 2015 season outside the calving ground, both west (approx. $100 \mathrm{~km}$ ) and east (approx. $160 \mathrm{~km}$ ) of Logans Beach. They were observed at the calving ground on 2 occasions during a 47-day period. The total number of calves (based on maximum number observed at any given time in a season) sighted at the Logans Beach calving ground from 1980 to 2018 is at least 93, with an average of $2.6 \pm 0.3$ ( $\pm \mathrm{SE}, n=39$ ) calves born each year. At least 56 calves have been born to the fifteen identified females at Logans Beach. We were unable to account for the mothers of the remaining 37 calves born at Logans Beach as the identities of calving females

\footnotetext{
${ }^{4}$ https://www.skadia.com.au/resources

${ }^{5}$ https://www.youtube.com/watch?v=fadf1eOMzi4
} 
Table 1

Year of first and last calf and mean calving interval for the 15 identified females that have calved at least once at Logans Beach nursery ground, Warrnambool, Victoria. SE: standard error.

\begin{tabular}{|c|c|c|c|c|c|c|c|}
\hline $\begin{array}{l}\text { Identification } \\
\text { number }\end{array}$ & First calf & Last calf & Total calves & $\begin{array}{c}\text { Minimum } \\
\text { interval }\end{array}$ & Maximum interval & Mean $( \pm S E)$ & Sample size \\
\hline SE9901* & 1982 & 2002 & 8 & 2 & 3 & $2.9 \pm 0.1$ & 7 \\
\hline SE0201 & 1995 & 2015 & 6 & 2 & 7 & $4.0 \pm 1.0$ & 5 \\
\hline SE0202 & 1995 & 2017 & 7 & 3 & 7 & $4.2 \pm 0.7$ & 6 \\
\hline SE0103 & 1996 & $2014 * *$ & 4 & 5 & 7 & $6.0 \pm 0.6$ & 3 \\
\hline SE0101 & 2001 & 2017 & 5 & 3 & 5 & $4.0 \pm 0.4$ & 4 \\
\hline SE0102 & 2002 & 2015 & 4 & 4 & 5 & $4.3 \pm 0.9$ & 3 \\
\hline SE0203 & 2002 & 2016 & 4 & 7 & 7 & $4.7 \pm 1.5$ & 3 \\
\hline SE0402 & 1995 & 2018 & 6 & 2 & 9 & $4.8 \pm 1.5$ & 5 \\
\hline SE0907 & 2009 & 2018 & 3 & 5 & 5 & & 2 \\
\hline SE0917 & 2009 & 2012 & 2 & 3 & 3 & & 1 \\
\hline SE0937 & $2009 * * *$ & 2017 & 2 & 8 & 8 & & 1 \\
\hline SE1338 & 2013 & 2017 & 2 & 4 & 4 & & 1 \\
\hline SE1335 & 2013 & & 1 & & & & \\
\hline SE1701 & 2017 & & 1 & & & & \\
\hline SE1702 & 2017 & & 1 & & & & \\
\hline TOTAL & All & & 56 & & & $4.2 \pm 0.3$ & 41 \\
\hline Excluding inte & $\operatorname{ars} * * * *$ & & & & & $3.5 \pm 0.2$ & 34 \\
\hline
\end{tabular}

*Went on to calve at Head of Bight in 2010, 2013 and 2017 ('Wilma'). **Was not seen at Logans Beach this year, but at Pink Bay in South Australia. ***Was not seen at Logans Beach in this year, but at Swanick in Tasmania. ****Except those that occurred between $2007-17$.

sighted prior to 2007 were not always obtained. However, given the apparent small number of reproductive females in the population, it is likely that some of these 37 calves were the offspring of the fifteen known females.

Calving intervals (i.e. the time, in years, between the sighting of consecutive calves) were calculated for each individual female seen with a calf in more than one season, over the duration of the study, then an average of those intervals was calculated. Twelve of the identified females were known to have calved at Logans Beach on two or more occasions with a mean calving interval of $4.2 \pm 0.3( \pm \mathrm{SE}, n=41)$ years. To allow for the possibility of non-detection, intervals of six years or more were excluded (Brandão et al., 2011; Burnell, 2001; Charlton, 2017; Cooke et al., 2001) unless these intervals occurred from 2007 to 2018, when it was less likely that calving females were not identified. This modified analysis produced a mean calving interval of $3.5 \pm 0.2( \pm \mathrm{SE}, n=34)$ years. The mean calving interval between 2007 and 2018 was $3.9 \pm 0.2$ years ( $\pm \mathrm{SE}, n=23$ ).

\section{Movement and connectivity between the south-eastern and south-western Australian regions}

Cross matching of the SEA SRW PIC against the ARWPIC resulted in twenty-six positive matches (i.e. 8\% of SEA SRW PIC whales were also found in ARWPIC). Four of these matches included whales seen outside of the southeastern Australian region (as defined by Carroll et al., 2015). When these matches were removed, 22 individual matches from 299 individual whales remained (Table S1). That is, 7\% of whales sighted in the south-eastern Australian Region were also sighted in the south-western Australian region. Nine of the 22 individuals matched between regions were females and the remaining individuals were adults of unknown sex. Maps showing the approximate location of matched females (i.e. females accompanied by a calf on at least one sighting event) and matched adults (i.e. whales not observed with a calf on any sighting event) are shown in Figs S1 and S2, respectively. Since Carroll et al. (2015) pooled genetic samples from whales at Port Fairy (30km west of Logans Beach) with those at Logans Beach and compared them to samples taken in the south-western Australian area, we wanted to investigate the degree of overlap between Port Fairy and the south-western Australian region. Of the 24 whales sighted at Port Fairy, five $(21 \%)$ had also been seen in the south-western Australia region, a much higher overlap than the overall rate between south-eastern and south-western Australia.

Seven within-season movements were detected, five of which were in a westerly direction and two in an easterly direction (Table S1). The longest within-season movement detected was $\sim 1,600 \mathrm{~km}$ (by female SE0501) from Cape Nelson, Victoria, to Head of Bight, SA (Table 2, Table S1, Fig. S1). The longest movement between 
(a)

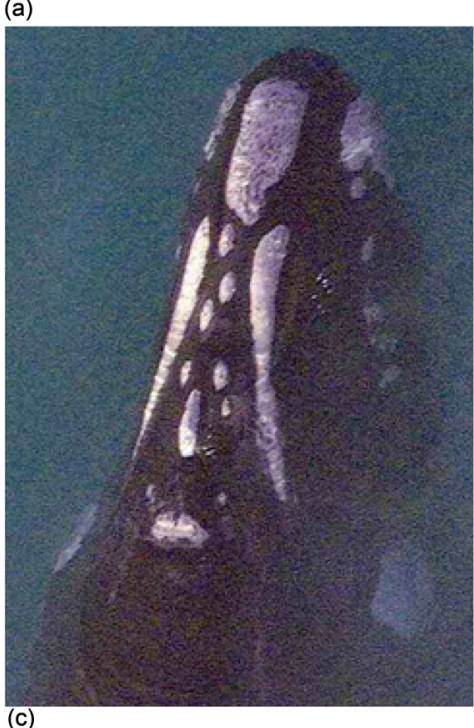

(c)

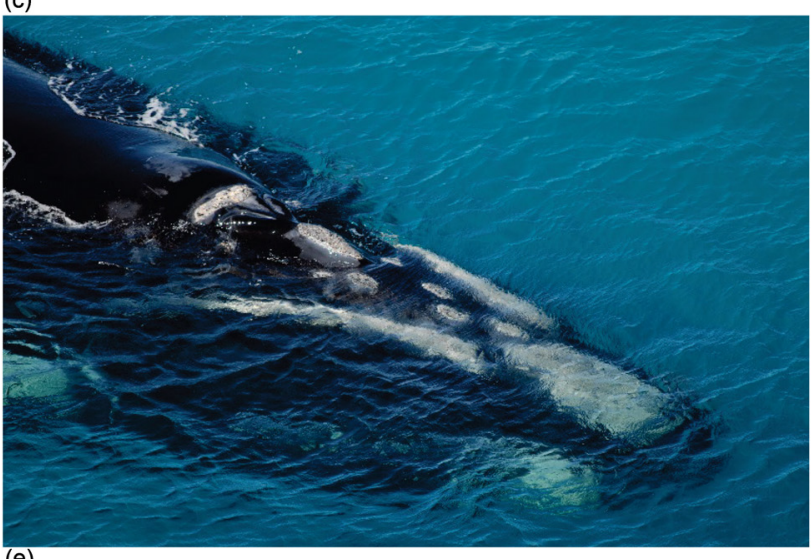

(e)

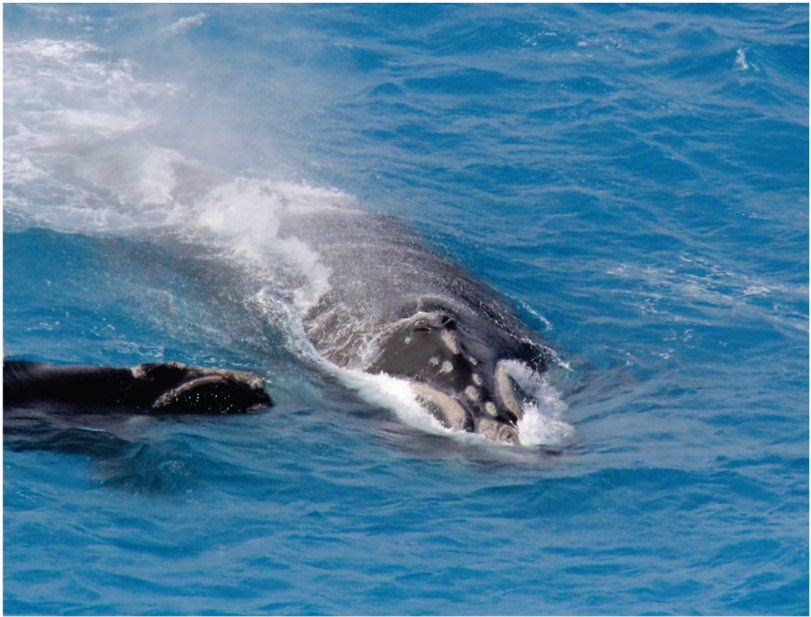

(b)
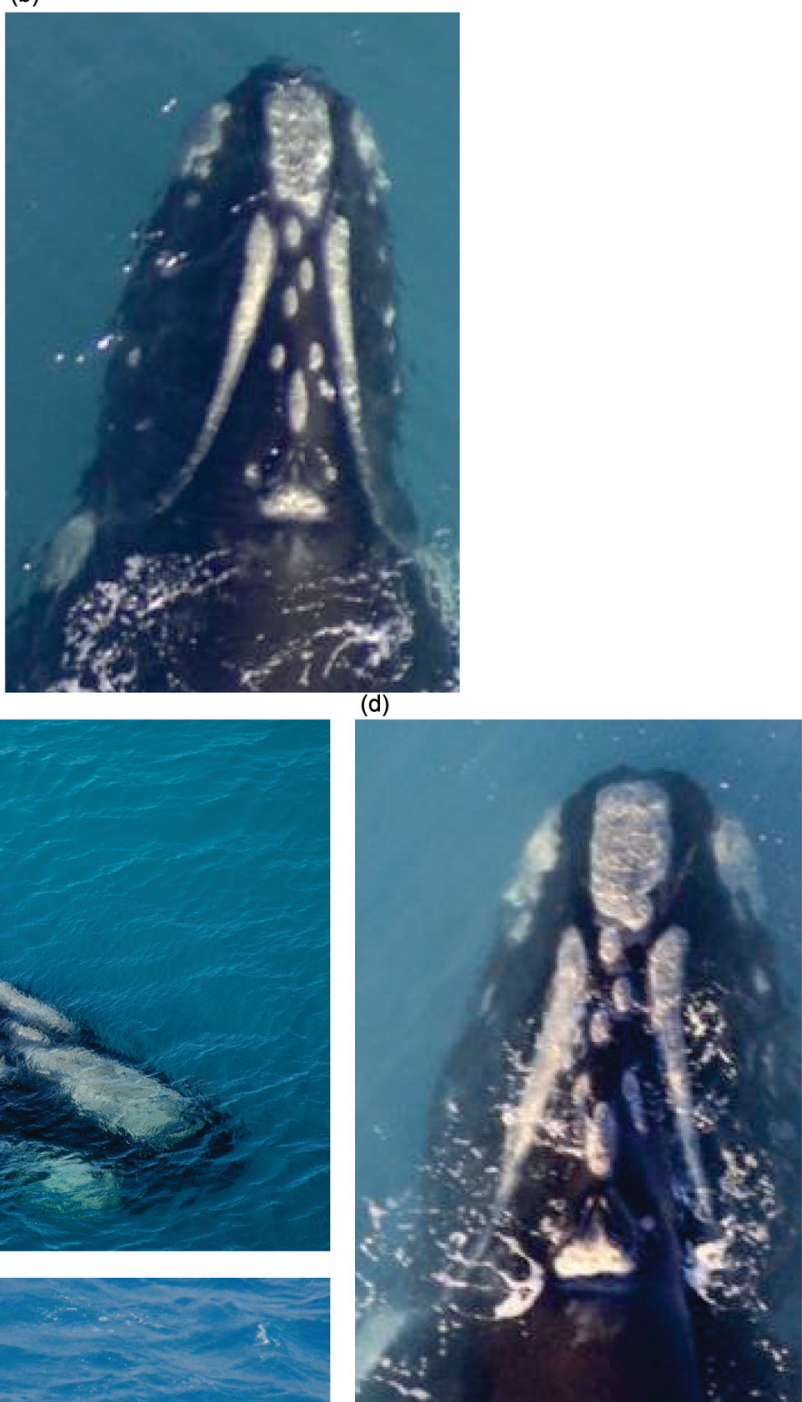

(f)

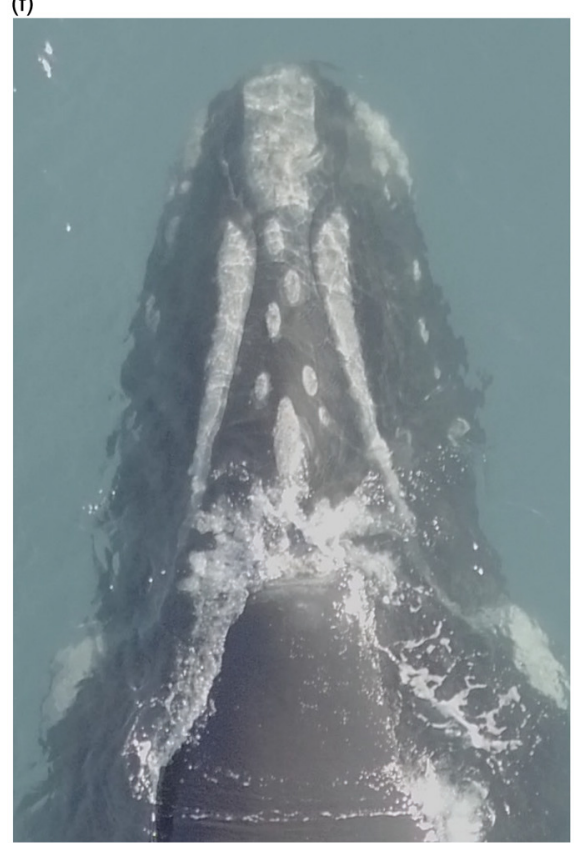

Fig. 2. (a) Photo of SE9901 'Wilma' at: (b) Logans Beach on 22/6/1999, Head of Bight on 21/8/2005, (c) Head of Bight on 20/8/2007, (d) Head of Bight on 12/8/2010, (e) Head of Bight on 20/8/2013 and (f) Head of Bight on 25/7/2017. Photo credit: F. Christiansen, Murdoch University. 
Table 2

The maximum distance between sightings for southern right whales matched between the Southeastern Australia Southern Right Whale Catalogue and the Australasian Right Whale Photo Identification Catalogue. Distances are approximate only.

\begin{tabular}{|c|c|c|}
\hline $\begin{array}{l}\text { Identification } \\
\text { number }\end{array}$ & $\begin{array}{c}\text { Maximum distance } \\
\text { between sightings }(\mathrm{km})\end{array}$ & Sex and age class \\
\hline SE9401 & 3,800 & Cow \\
\hline SE9501 & 2,200 & Cow \\
\hline SE9502 & 2,300 & Cow \\
\hline SE9516 & 1,500 & Cow \\
\hline SE9901 & 1,600 & Cow \\
\hline SE0210 & 3,800 & Adult \\
\hline SE0401 & 2,600 & Adult \\
\hline SE0501 & 2,500 & Cow \\
\hline SE0804 & 2,800 & Adult \\
\hline SE0805 & 2,200 & Cow \\
\hline SE0911 & 2,100 & Adult \\
\hline SE1009 & 1,100 & Adult \\
\hline SE1101 & 1,800 & Adult \\
\hline SE1103 & 2,200 & Cow \\
\hline SE1104 & 3,000 & Adult \\
\hline SE1112 & 2,400 & Cow \\
\hline SE1114 & 2,500 & Adult \\
\hline SE1207 & 2,000 & Cow \\
\hline SE1209 & 2,100 & Adult \\
\hline SE1216 & 2,200 & Adult \\
\hline SE1218 & 2,600 & Adult \\
\hline SE1321 & 2,200 & Adult \\
\hline SE1323 & 1,700 & Adult \\
\hline SE1405 & 2,100 & Adult \\
\hline SE1506 & 2,500 & Adult \\
\hline
\end{tabular}

years was from Sydney, NSW, to Israelite Bay, WA $(\sim 3,800 \mathrm{~km})$ by an adult female (SE9401) and an adult of unknown sex (SE0210) (Table 2, Table S1, Fig. S2). One female (SE9901, 'Wilma') calved at Logans Beach seven times over a 17-year period (1985-2002) before being sighted 1,600km away to the west at Head of Bight in 2005 without a calf and then again with a calf four times in ten years (2007, 2010, 2013 and 2017; Table S1, Fig. S1, Fig. 2). Early newspaper records indicate that SE9901 was also present at Logans Beach in 1982, although they do not say whether she was with a calf. None of the other identified females that had calved at Logans Beach were detected in the ARWPIC, Eubalaena or Fowlers Bay catalogues.

\section{DISCUSSION}

The size of the south-eastern Australian southern right whale subpopulation is significantly lower than that of the south-western Australian subpopulation and is at only $1 \%$ of the estimated number of southern right whales harvested in the south-eastern region between 1827 and 1975 (Carroll et al., 2014). Historical records show that shore-based whaling pressure was much greater in the south-eastern Australian region than in the south-western Australian region, with $83 \%$ of the 115 shore-based stations located in south-eastern Australia (Pirzl, 2008). The practice of shore-based whaling inherently targeted females and calves and given that southern right whales exhibit strong site fidelity, it is likely that local extirpation has led to a memory loss of calving areas (Carroll et al., 2015), limiting recovery in the south-eastern subpopulation.

Logans Beach, Warrnambool is currently the only established southern right whale calving and nursery ground in south-eastern Australia (DSEWPaC, 2012). Despite at least 93 calves being born at Logans Beach between 1980 and 2018 (an average of 2.6 per year), modelling of both photo-identification and sighting data (1985-2017) shows that there has been no significant change in the annual abundance of cow-calf pairs in the south-eastern Australian region in more than three decades (Stamation et al., 2020). Predictions based on observed calving intervals at Logans Beach and population parameters from the literature, however, show that the observed number of breeding females is within the expected range (Stamation et al., 2020). This highlights the slow nature 
of recovery in small populations of long-lived animals with low reproductive rates (Keevil et al., 2018). Given that Logans Beach is the only currently established calving ground in south-eastern Australia, the protection of breeding females from anthropogenic threats operating there and in other historical high use areas will be critical for recovery of the species in this region.

There is currently no conclusive evidence for range expansion in the south-eastern Australian subpopulation. There are four documented cases in the SEA SRW PIC of mother-calf pairs using bays in south-west Victoria outside Logans Beach for extended periods during the season. There are also records of short-term use by mother-calf pairs along the Victorian, Tasmanian and southern NSW coastline from May to September (Stamation et al., 2020). On the contrary, range expansion has been reported for southern right whales in other parts of their range, including South Australia (Charlton et al., 2019b), Argentina and Brazil (Danilewicz et al., 2016; Rowntree et al., 2001; Seyboth et al., 2016) South Africa (Barendse and Best, 2014) and New Zealand (Carroll et al., 2011; Carroll et al., 2014). Sighting data collected from outside Logans Beach is primarily incidental, with sporadic aerial surveys conducted along the south-eastern Australian coastline over the last 3 decades (Kemper et al., 1997; Watson et al., 2014). Long-term monitoring of southern right whales on the migratory corridors in south-east Australia, running parallel with the program in south-western Australia (Bannister, 2011; Bannister et al., 2011) would help detect any emerging calving grounds in the region.

The mean calving interval observed at Logans Beach of $4.2 \pm 0.3$ is long, with some calving intervals as long as 7 and 9 years. When adjusted to allow for non-detections (i.e. excluding intervals of $\geq 6$ years prior to 2007), the mean calving interval ( $3.5 \pm 0.2$ years) is closer to that observed elsewhere, such as: 3.35 years $(S E=0.05)$ in Argentina (Cooke et al., 2001), 3.12 years $(95 \% \mathrm{Cl}: 3.05,3.17)$ in South Africa (Best et al., 2001) and 3.3 years ( $S D=0.8 \pm 0.3,95 \% \mathrm{Cl}$ ) at the Head of Bight, SA (Charlton, 2017). Detection rates at Logans Beach between 2007 and 2018 are likely to be comparatively high as consistent monitoring was undertaken during this period. The calving interval for this period ( $3.9 \pm 0.2)$ is longer than elsewhere, suggesting that some females from the southeastern subpopulation may be calving less often or occasionally calving in other areas. Only one of the 15 identified females from Logans Beach has been found at another calving ground, but comparison with New Zealand catalogues has not yet been undertaken. Given that there is no significant genetic differentiation between females at the Auckland Islands calving ground and Logans Beach (Carroll et al., 2011; Carroll et al., 2015), movement between these two calving grounds should be explored further. In recent years, fluctuations in southern right whale counts across wintering grounds and elongation of calving intervals have been observed elsewhere (Charlton, 2017; Vermeulen et al., 2018), with short-term (at least) effects on the population growth rate (Brandão et al., 2018). Given that food availability has been strongly linked to the reproductive success of southern right whales (Leaper et al., 2006; Seyboth et al., 2016) and the predicted negative future impacts of climate change (i.e. reduced prey from warming and interspecific competition) (see Tulloch et al., 2019) there is increasing concern around what these observed increase in calving intervals could mean for southern right whale populations globally. Increased effort is required to investigate the biological processes affecting population dynamics in this already small south east subpopulation.

Our study shows that a significant number of calves (at least 93) have been born at Logans Beach since 1980 demonstrating that it is a critical habitat for calving and nursing southern right whales, despite no significant increase in the annual number of females using this calving ground (Stamation et al., 2020). A better understanding of juvenile survival, recruitment and natal site fidelity in the south-eastern Australian subpopulation is needed to better appreciate constraints or stressors that may be affecting population growth in the region. This knowledge gap could be reduced by expanding photo-identification monitoring (including the use of high-quality imagery from remotely piloted aircraft systems) to collect data on calves, photo-identification matching work to explore links between the south-east Australian and New Zealand populations and long-term genetic sampling (as per Carroll et al., 2016).

Long-range movements of southern right whales in Australian waters were first documented by Burnell (2001). His observations included between-year movements (with a maximum of 2,287km) of eight individuals from SA to Tasmania, SA to NSW, SA to Victoria, Victoria to WA and between Tasmania and WA. Three within-year movements between SA and Victoria and Victoria and NSW were also recorded. At the time of Burnell's study 
(2001), data from the south-eastern Australia region were lacking. With the establishment of the SEA SRW PIC and ARWPIC datasets, we have been able to expand our understanding of the movement of southern right whales in Australian waters. Our records show that southern right whales are ranging widely within Australian waters and that females can be sighted at locations as far apart as $3,800 \mathrm{~km}$ across seasons.

Our results support the counter-clockwise migration theory proposed by Burnell (2001) where whales from the south-western subpopulation arriving on the Australian coast from summer feeding grounds in the south, move in a circular anti-clockwise direction into south-eastern Australia before traveling west to calving grounds in SA and WA. Five of seven within-season movements detected here were in a westerly direction. Results from the present study indicate that at least 7\% of whales in the SEA SRW PIC catalogue are using both the southeastern and south-western regions. This is consistent with the findings of Carroll et al. (2015) that mixing of whales from genetically distinct populations is occurring on the migratory corridors. We report that $21 \%$ of whales sighted at Port Fairy also use western Australia, so it is likely that the five Port Fairy samples used by Carroll et al. (2015) included individuals from the south-western subpopulation. These findings bring into question the degree of separation of the south-eastern and south-western Australian subpopulation ranges and support the suggestion that pooling of calving ground samples with migratory corridor samples probably led to the nondifferentiation between the two management units (Carroll et al., 2015).

A significant finding of this study is the first report in Australian waters, as far as we are aware, of a female from one subpopulation relocating to a calving ground in another, long-term. Calving female SE9901 ('Wilma') had shown strong calving site fidelity to Logans Beach in south-east Australia before shifting to the Head of Bight calving ground in south-west Australia. This female was last seen at Logans Beach with a calf in 2002 before being sighted without a calf at Head of Bight in 2005 and then again, with a calf, at Head of Bight in 2007, 2010, 2013 and 2017. Southern right whales are known to have strong natal site fidelity (e.g. Best, 1993; Burnell, 2001; Carroll et al., 2015; Carroll et al., 2016; Charlton, 2017; Rowntree et al., 2001), although shifting of calving grounds has been recorded previously (Best, 1993; Charlton, 2017; Pirzl et al., 2009). There are examples in the literature of females shifting to calving grounds within population boundaries (Burnell, 2001; Charlton, 2017) as well as between population-specific calving grounds (Best, 1993; Pirzl et al., 2009). Pirzl et al. (2009) document two instances of females calving at two different population-specific calving grounds (Head of Bight, SA, and Auckland Islands, New Zealand), three and four years apart. In one of these cases, fidelity to the Head of Bight calving ground was presumed to be weak as the female was only seen in one season despite decades of survey effort in the area and was only seen on one day compared with an average residency time for cow-calf pairs of 71 days (Pirzl et al., 2009). The second case was of a female sighted at Head of Bight in 1990 and 1993 before calving in the Auckland Islands in 1996 and then calving again at Head of Bight in 2000 (Pirzl et al., 2009). None of the previously reported cases showed long-term re-selection.

The reason for 'Wilma' abandoning the Logans Beach calving ground long term is unclear. It has been suggested by Pirzl et al. (2009) that movements of females between calving grounds may be density dependent, so, we may expect to see more examples of this occurrence as populations recover. Recent shifts in distribution due to population expansion noted in Argentina (Arias et al., 2017; Carroll et al., 2014; Charlton, 2017; Crespo et al., 2017) would support this theory. However, the density-dependence hypothesis does not necessarily fit with the case of 'Wilma'. As reported here, Logans Beach is a low-density calving ground with an average of only 2.6 calves produced per year compared to the Head of Bight area, where counts of up to 81 individual cow-calf pairs have been recorded in a day (Charlton, 2017).

It is clear from our work that there is overlap in the wintering ranges of the south-western and south-eastern subpopulations. This overlap may facilitate gene flow between calving grounds if successful mating between individuals from the separate populations is occurring in these areas (Carroll et al., 2015). Observations of surfaceactive groups observed in Victorian waters by Watson while collecting SEA SRW PIC data, and genetic samples, indicate that mating behaviour is occurring in the migratory corridor. This includes direct observations of mating groups in Victoria near Warrnambool in 2009 and 2012; Port Fairy in 2009, 2011 and 2012; and Portland in 2010. Photographic evidence and reports received from other observers also suggest mating behaviour has occurred at numerous south-eastern Australian locations such as Cape Nelson, Portland, Port Fairy, Apollo Bay, Wilson's 
Promontory, Raymond Island and Lake Tyres in Victoria, and Mossy Point in NSW. It is likely that these groups include a mixture of south-western and south-eastern individuals. One breeding female (SE0501) observed in a mating group at Cape Nelson in 2005 was seen two months later at Head of Bight and calved at Doubtful Island Bay in 2010 (she had previously been sighted at Baxter Cliffs, SA, in 2000 and in the Hopetoun Area, WA, in 2004). It is not known whether these copulation events lead to conception. Gestation for southern right whales is estimated at 11-12 months (Best et al., 2001; Burnell, 2001) and only two of the 42 cows identified in southeastern Australia were seen on the Australian coast the year prior to calving. This is consistent with reports elsewhere and suggests that either mating females have very brief residence times (and thus go undetected) or that conception is occurring outside coastal waters (Best, 1994; Payne, 1986). If breeding between the southwestern and south-eastern populations is occurring, it would contrast with the findings Carroll (2012), who found using paternity testing, that whales using the same calving grounds in New Zealand were mating together.

The photo-identification records of 'Wilma' suggest that some interchange between genetically differentiated populations is likely. This would provide a mechanism for fidelity-mediated gene flow (i.e. where a female conceives in the population with which she is genetically affiliated and then gives birth in a different population range). It is then assumed that the offspring will show fidelity to and presumably breed within its birthing population (Pirzl et al., 2009).

In conclusion, our study provides substantial evidence that southern right whales are ranging widely within southern Australian waters and that the wintering range of the south-eastern and south-western subpopulations overlap, at least to some degree. We also found that southern right whale females from one subpopulation can reselect calving habitat in another, long term. We provide the first assessment of calving intervals at Logans Beach and the basis for future monitoring of this subpopulation. While there have been key learnings arising from this work, it has also exposed several knowledge gaps. Basic population dynamic information, critical for management of the south-east Australian southern right whale subpopulation, is missing. We do not know where and when conception occurs for the south eastern subpopulation, where feeding grounds are located and where non-breeding whales spend the winter months. In addition, the degree of mixing between subpopulations outside the wintering areas and what proportion of female calves born at Logans Beach are returning to their natal site to calve remains unclear. Long-term monitoring programs of southern right whales across south-eastern Australia and into the subAntarctic feeding grounds are required to identify population trends and any stressors that may affect population growth, recovery and range expansion in the south-eastern Australian region. Resolving these questions is critical for understanding the recovery potential of the heavily depleted south-eastern Australian population and informing decision making regarding the need for management of anthropogenic threats such as noise disturbance, entanglement and vessel strike, operating at historically important calving areas within this region.

\section{ACKNOWLEDGMENTS}

The authors wish to acknowledge the contributions of the late John Bannister whose south-western Australian photo-identification data formed a significant part of this study and whose comments on the earliest draft of this paper were gratefully received. John sadly passed away during the preparation of this paper. We thank Robert Harcourt (Macquarie University) and Nathalie Patenaude (Collégial International Sainte-Anne) for contributing photo-identification data from south-eastern Australia and Fredrik Christiansen (Murdoch University) for contributing UAV photo-identification data on Wilma from Head of Bight for this study. We are grateful to the government staff and volunteers across Victoria, SA, Tasmania and NSW who have contributed data to the catalogues, in particular, Peter Read, who contributed observations between 2007 and 2018. Much of the data from the 1990s was provided by Dr. Stephen Burnell. Rachel Alderman co-ordinated the incorporation of Tasmanian data into ARWPIC. Technical support for ARWPIC was provided by the Australian Marine Mammal Centre, Virginia Andrews-Goff, Andy Townsend and Mike Double, as well as Keiran Lawton from Skadia Pty Ltd. Comments from Peter Menkhorst (Arthur Rylah Institute for Environmental Research), Emma Carroll (The University of Auckland) and professional editor Lucie Bland greatly improved earlier drafts of this manuscript. Funding for the matching between the SEA SRW PIC and ARWPIC was provided by the Victorian Government's 2015 Threatened Species Protection Initiative (TSPI). 


\section{REFERENCES}

Arias, M., Coscarella, M., Svendsen, G., Romero, M.A., Curcio, N., Sueyro, N., Crespo, E. and Gonzalez, R. 2017. Changes in the distribution and abundance of southern right whale Eubalaena australis in San Matias Gulf (Patagonia, Argentina). Paper SC/67a/CMP06 presented to the IWC Scientific Committee, May 2017, Bled, Slovenia (unpublished). 14pp. [Paper available from the Office of this Journal].

Bannister, J. 2011. Population trend in right whales off southern Australia 1993-2010. Paper SC/S11/RW10 presented to the Southern Right Whale Assessment Workshop, 13-16 September 2011, Buenos Aires, Argentina (unpublished). 8pp. [Paper available from the Office of this Journal].

Bannister, J.L. 1990. Southern right whales off western Australia. Rep. Int. Whaling Commn. (special issue) 12: 279-88.

Bannister, J.L. 2018. Monitoring Population Dynamics of 'Western' Right Whales off Southern Australia 2015-2018 - Final Report on activities for 2017. Report to the National Environmental Science Programme, Marine Biodiversity Hub. Western Australian Museum (lead organisation).

Bannister, J.L., Hedley, S.L., Bravington, M.V. and Burnell, S.R. 2011. Monitoring population dynamics of right whales off southern Australia. Project 2009/41: Final Report to the Australian Marine Mammal Centre, 13 April 2011. 23pp.

Barendse, J. and Best, P.B. 2014. Shore-based observations of seasonality, movements, and group behaviour of southern right whales in a non-nursery area on the South African west coast. Mar. Mamm. Sci. 30(4): 1358-82. [Available at: https://doi.org/10.1111/ $m m s .12116]$

Best, P.B. 1990. Natural markings and their use in determining calving intervals in right whales off South Africa. S. Afr. J. Zool. 25(2): 11423.

Best, P.B. 1993. Increase rates in severely depleted stocks of baleen whales. ICES J. Mar. Sci. 50(3): 169-86.

Best, P.B. 1994. Seasonality of reproduction and the length of gestation in southern right whales Eubalaena australis. J. Zool. 232: 17589.

Best, P.B., Brandão, A. and Butterworth, D.S. 2001. Demographic parameters of southern right whales off South Africa. J. Cetacean Res. Manage. 2: 161-69.

Brandão, A., Best, P.B. and Butterworth, D.S. 2011. Monitoring the recovery of the southern right whale in South African waters. Paper SC/S11/RW18 presented to the Southern Right Whale Assessment Workshop, 13-16 September 2011, Buenos Aires, Argentina (unpublished). 18pp. [Paper available from the Office of this Journal].

Brandão, A., Vermeulen, E., Ross-Gillespie, A., Findlay, K. and Butterworth, D.S. 2018. Updated application of a photo-identification based assessment model to southern right whales in South African waters, focussing on inferences to be drawn from a series of appreciably lower counts of calving females over 2015 to 2017. Paper SC/67b/SH22 presented to the IWC Scientific Committee, April-May 2018, Bled, Slovenia (unpublished). 19pp. [Paper available from the Office of this Journal].

Burnell, S.R. 2001. Aspects of the reproductive biology, movements and site fidelity of right whales off Australia. J. Cetacean Res. Manage. (Special issue) 2: 89-102.

Burnell, S.R. 2008. Estimates of demographic population parameters of southern right whales off Australia. Paper SC/60/BRG12 presented to the IWC Scientific Committee, June 2008, Santiago, Chile (unpublished). 8pp. [Paper available from the Office of this Journal].

Carroll, E. 2012. Paternity assignment and demographic closure in the New Zealand southern right whale. Mol. Ecol. 21(16): 3960-73. [Available at: $h$ ttps://doi.org/10.111/j.1365-294X.2012.05676.x].

Carroll, E., Patenaude, N., Alexander, A., Steel, D., Harcourt, R., Childerhouse, S., Smith, S., Bannister, J., Constantine, R. and Baker, C.S. 2011. Population structure and individual movement of southern right whales around New Zealand and Australia. Mar. Ecol. Prog. Ser 432: 257-68.

Carroll, E.L., Baker, C.S., Watson, M., Alderman, R., Bannister, J., Gaggiotti, O.E., Grocke, D.R., Patenaude, N. and Harcourt, R. 2015. Cultural traditions across a migratory network shape the genetic structure of southern right whales around Australia and New Zealand. Sci. Rep. 5: 16182. [Available at: https://doi.org/10.1038/srep16182].

Carroll, E.L., Fewster, R.M., Childerhouse, S.J., Patenaude, N.J., Boren, L. and Baker, C.S. 2016. First direct evidence for natal wintering ground fidelity and estimate of juvenile survival in the New Zealand southern right whale Eubalaena australis. PLoS One. [Available at: $h$ ttps://doi.org/10.131/journal.pone.0146590].

Carroll, E.L., Jackson, J.A., Paton, D. and Smith, T.D. 2014. Two Intense Decades of 19th Century Whaling Precipitated Rapid Decline of Right Whales around New Zealand and East Australia. PLoS One 9(4): e93789. [Available at: https://doi.org/10.1371/ journal.pone.0096729].

Charlton, C. 2017. Southern right Whale (Eubalaena australis) Population Demographics in Southern Australia, PhD thesis, Curtin University, Western Australia. 173pp. [Aailable at: $h$ ttps://doi.org/10.1002/aqc.3032].

Charlton, C., Ward, R., McCauley, R.D., Brownell Jr, R.L., Kent, C.S. and Burnell, S. 2019a. Southern right whale (Eubalaena australis), seasonal abundance and distribution at Head of Bight, South Australia. Aquat. Conserv. 29(4): 576-88.

Charlton, C., Ward, R., McCauley, R.D., Brownell Jr, R.L., Guggenheimer, S., Salgado Kent, C.P. and Bannister, J.L. 2019b. Southern right whales (Eubalaena australis) return to a former wintering calving ground: Fowlers Bay, South Australia. Mar. Mamm. Sci. 35(4): 143862.

Cooke, J.G., Rowntree, V.J. and Payne, R.S. 2001. Estimates of demographic parameters for southern right whales (Eubalaena australis) observed off Península Valdés, Argentina. J. Cetacean Res. Manage. 2: 125-32.

Crespo, E.A., Coscarella, M.A., Pedraza, S.N., Dans, S.L., Svendsen, G.M. and Degrati, M. 2017. Southern right whales Eubalaena australis still growing but at a decelerated speed. Paper SC/67a/CMP01 presented to the IWC Scientific Committee, May 2017, Bled, Slovenia (unpublished). 15pp. [Paper available from the Office of this Journal].

Danilewicz, D., Moreno, I.B., Tavares, M. and Sucunza, F. 2016. Southern right whales (Eubalaena australis) off Torres, Brazil: group characteristics, movements, and insights into the role of the Brazilian-Uruguayan wintering ground. Mammalia 83(3). [Available at: https://doi.org/10.1515/mammalia-2015-0096]. 
Harcourt, R., van der Hoop, J., Kraus, S. and Carroll, E.L. 2019. Future Directions in Eubalaena spp.: Comparative Research to Inform Conservation. Front. Mar. Sci. 5(530). [Available at: https://doi.org/10.3389/fmars.2018.00530].

Jackson, J.A., Patenaude, N.J., Carroll, E.L. and Baker, C.S. 2008. How few whales were there after whaling? Inference from contemporary mtDNA diversity. Mol. Ecol. 17: 236-51. [Available at: $h$ ttps://doi.org/10.1111/j.1365-294X.2007.03497.x].

Keevil, M.G., Brooks, R.J. and Litzgus, J.D. 2018. Post-catastrophe patterns of abundance and survival reveal no evidence of population recovery in a long-lived animal. Ecosphere 9(9). [Available at: $h$ ttps://doi.org/10.1002/ecs2.2396].

Kemper, C.M., Mole, J., Warneke, R.M., Ling, J.K., Needham, D.J. and Wapstra, J.E. 1997. Southern right whales in south eastern Australia - aerial surveys during 1991-93 and incidental information from 1904. pp.40-45. In: Hindell, M. and Kemper, C. (eds). Marine Mammal Research in the Southern Hemisphere. Surrey Beatty and Sons Pty Ltd, Chipping Norton, New South Wales.

Leaper, R., Cooke, J., Trathan, P., Reid, K. and Rowntree, V. 2006. Global climate change drives southern right whales (Eubalaena australis) population dynamics. Biol. Lett. 2: 289-92. [Available at: $h$ ttps://doi.org/10.1098/rsbl.2005.0431].

Payne, R. 1986. Long term behavioral studies of the southern right whale (Eubalaena australis). Rep. Int. Whaling Commn. (special issue) 10: 161-67.

Payne, R., Brazier, O., Dorsey, E.M., Perkins, J.S., Rowntree, V.J. and Titus, A. 1983. External features in southern right whales (Eubalaena australis) and their use in identifying individuals. pp.371-445. In: Payne, R. (eds). Communication and Behavior of Whales. AAAS Selected Symposia Series 76. Westview Press, Colorado. xii+643pp.

Pirzl, R. 2008. Spatial ecology of Eubalaena australis: habitat selection at multiple scales, School of Life and Environmental Sciences, Deakin University, Melbourne, Melbourne.

Pirzl, R., Lawton, K. and Murdoch, G. 2007. Development of a data management system for southern right whale monitoring at Head of Bight, South Australia. Final Report to South Australian Department for Environment and Heritage, Adelaide, Australia (unpublished).

Pirzl, R., Patenaude, N.J., Burnell, S. and Bannister, J. 2009. Movements of southern right whales (Eubalaena australis) between Australian and subantarctic New Zealand population. Mar. Mamm. Sci. 25(2): 455-61. [Available at: https://doi.org/10.1111/j.1748-7692. 2008.00276.x].

Rowntree, V.J., Payne, R. and Schell, D.M. 2001. Changing patterns of habitat use by southern right whales (Eubalaena australis) on their nursery ground at Península Valdés, Argentina, and in their long-range movements. J. Cetacean Res. Manage. 2: 133-43.

Seyboth, E., Groch, K.R., Dalla Rosa, L., Reid, K., Flores, P.A. and Secchi, E.R. 2016. Southern right whale (Eubalaena australis) reproductive success is influences by krill (Euphausia superba) density and climate. Sci. Rep. 6(28205). [Available at: https://doi.org/10.1038/ srep28205].

Skalski, J.R., Ryding, K.E. and Millspaugh, J. 2005. Wildlife Demography: Analysis of Sex, Age and Count Data. Elsevier Academic Press. $656 \mathrm{pp}$.

Smith, J.N., Jones, D., Travouillon, K., Kelly, M., Double, M. and Bannister, J.L. 2020. Monitoring population Dynamics of 'Western' Right Whales off Southern Australia 2018-2021 - Final Report on activities for 2019. Report to the National Environmental Science Program, Marine Biodiversity Hub. Western Australian Museum (lead organisation). [Available at: $h$ ttps://www.nespmarine.edu.au/system/ files/Jones_Travouillon\%20A7\%20Monitoring\%20population\%20dynamics\%20right\%20whales\%20Final\%20report\%20for\%202019_ Milestone\%2012.pdf].

Stamation, K., Watson, M., Moloney, P., Charlton, C. and Bannister, J. 2020. Population Estimate and Rate of Increase of Southern Right Whales, Eubalaena australis in South-eastern Australia. Endanger. Species Res.: 22pp. [Available at: $h$ ttps://doi.org/10.3354/esr01031].

Tulloch, V.J.D., Plagányi, É.E., Brown, C., Richardson, A.J. and Matear, R. 2019. Future recovery of baleen whales is imperilled by climate change. Global Change Biology: 1-19. [Available at: $h$ ttps://doi.org/10.1111/gcb.14573].

Vermeulen, E., Wilkinson, C., Thornton, M., Peters, I.T. and Findlay, K. 2018. Report on the Mammal Research Institure Whale Unit southern right whale survey - 2017. Paper SC/67b/SH01 presented to the IWC Scientific Committee, April-May 2018, Bled, Slovenia (unpublished). 24pp. [Paper available from the Office of this Journal].

Watson, M., Westhorpe, I., Bannister, J., Harcourt, R. and Hedley, S. 2014. Australian Marine Mammal Centre Grants Program Final Report for Project 12/29: Assessment of number and distribution of southern right whales in south east Australia., Macquarie University, https://data.marinemammals.gov.au/common/documents/grants/2013/13_29_Watson_Westhorpe.pdf.

Watson, M., Westhorpe, I., Bannister, J., Harcourt, R. and Hedley, S. 2015. Australian Marine Mammal Centre Grants Program Final Report for Project 13/29: Assessment of numbers and distribution of southern right whales in south-east Australia - Year 2, Macquarie University.

Zerbini, A.N., Clapham, P.J. and Wade, P.R. 2010. Assessing plausible rates of population growth in humpback whales from life-history data. Mar. Biol. 157(6): 1225-36. [Available at: https://doi.org/10.1007/s00227-010-1403-y]. 